\title{
Design of an Earth Air Heat Exchanger (EAHE) for Climatic Condition of Chennai, India
}

\author{
G.N. Tiwari", Vikram Singh, Poonam Joshi, Shyam, Arjun Deo, Prabhakant and Agam Gupta \\ Centre for Energy Studies, Indian Institute of Technology Delhi, Hauz Khas, New Delhi 110016, India
}

\begin{abstract}
In the present work the ground temperature has been validated for climatic condition of Sriperumbudur near Chennai, India to evaluate thermal conductivity and diffusivity of the soil. For the evaluated thermal conductivity of the soil, an EAHE has been designed for a given dimension of room with optimized values of number of air changes, length of pipe, radius of pipe and depth at which heat exchanger to be installed below the surface of the earth. It has been observed that there is a decrease of $5-6{ }^{0} \mathrm{C}$ in the outlet air temperature in summer for a number of 5 air changes with $0.10 \mathrm{~m}$ and $21 \mathrm{~m}$ optimized diameter and length of pipe respectively.
\end{abstract}

Keywords: Earth air heat exchanger, constant ground temperature, geothermal energy.

\section{INTRODUCTION}

The ground temperature below earth surface is nearly constant after a certain depth depending upon the soil properties and climatic condition. This property is being applied to cool or heat the ambient air since a very long time. This concept has been used to cool or heat the room air to reduce the load for cooling or heating by conventional methods. Sodha et al. [1] found variance in ground temperature using Fourier coefficient calculations and predicted that the variance decreases rapidly with depth and temperature approaches to a constant value after $0.4 \mathrm{~m}$ depth. Recently, Onder Ozgener et al. [2] gave a practical approach to predict the soil temperature from daily air temperature data for earth air heat exchanger (EAHE) applications assuming one dimensional heat flow and constant thermal conductivity and thermal diffusivity of soil. The concept of indirect coupling to heat the room air has been presented by Bowen et al. [3]. Since then, several studies covering theoretical modelling, experimental studies, for different ground cover, for different climatic conditions and for different places around the globe have been conducted [4-8]. Bojic et al. [9] gave thermal modeling for two pipes of different materials dividing the pipes and soil in elemental volume. Jens Pfafferott [10] calculated the energy efficiency of EAHE and found that thermal efficiency depends on instantaneous changes in temperature. Ghoshal et al. [11] found that for greenhouse heating, the ground air collector was a suitable option compared to EAHE for their studied system and climatic condition. Nayak and Tiwari $[12,13]$ studied the photovoltaic integrated greenhouse coupled with the EAHE and estimated the energy matrices of the system for Indian climates. The evaporative cooling can enhance the performance of EAHE as suggested by Bansal et al. [14].

*Address correspondence to this author at the Centre for Energy Studies, Indian Institute of Technology Delhi, Hauz Khas, New Delhi 110016, India; Tel: +91 11 26591258; Fax: +91 11 26592208;

E-mail: gntiwari@ces.iitd.ernet.in
Arif Hepbasli [15] presented the low exergy model to evaluate a greenhouse coupled with EAHE and inferred that the higher reference temperature decreases the exergy efficiency of the whole system. Clara Peretti et al. [16] and Bisnoyia et al. [17] gave an extensive literature review covering design, characteristics of EAHE, modelling adopted by several researchers etc. When the earth air heat exchanger was integrated by solar chimney which utilizes both the geothermal energy as well as the solar energy, the energy savings were greater compared to uncoupled system [18]. Chlela et al. [19] concluded that a balanced ventilation system coupled with EAHE significantly reduces a building's heat demand and hence its $\mathrm{CO}_{2}$ emissions. Clara Peretti et al. [16] discussed the effect of soil cover, climate and soil composition on the performance of the EAHE and concluded that the bare surface improves the performance of the EAHE for heating whereas the wet surface is better for cooling purpose. It has also been concluded that higher water content and closely packed soil near the pipes of EAHE improves the performance of the EAHE. Rodriguez and Diaz [20] studied the mine galleries converted into EAHE and discussed the importance of such systems from a technical, economical and environmental point of view. Stephane Thiers and Bruno Peuportier [21] analyzed the performance of a passive building coupled with EAHE in France. They have concluded that the passive concept efficiently enhances the environmental performance of the dwellings in the French context. Mishra et al. [22] experimentally investigated the performance of the hybrid EAHE and concluded that energy consumption was reduced by $18 \%$ when the conditioned air from EAHE was utilized for condenser cooling compared to the energy consumption when ambient air was used for condenser cooling.

\section{EARTH AIR HEAT EXCHANGER}

An EAHE exploits the constant ground temperature few meters below the earth surface for cooling or heating the air inside the pipe buried below the earth surface. The diameter, length of pipe and depth of heat exchanger below ground, 
dampness of the earth, humidity of inlet air and its velocity play a vital role in determining the heat exchange between air and the surrounding soil. The air flowing inside the pipe gets/rejects heat from/to the inner surface of pipe by forced convection and heated/cooled depending upon ground temperature and air temperature of flowing air inside the pipe.

\section{THERMAL MODELING}

Thermal modeling of the present study is divided into two part parts

evaluation of the temperature distribution below the ground surface and

(ii) the expression for the air temperature at the outlet of the EAHE.

\section{Temperature Distribution for Semi-Infinite Surface}

Heat conduction equation governs the temperature at any point in the given region with the help of set of initial and boundary condition.

The equation governing the temperature distribution $T$ $(x, t)$ is given by,

$\frac{K}{\rho c} \frac{\partial^{2} T}{\partial x^{2}}=\frac{\partial T}{\partial t}$

If the boundary conditions, meteorological parameters etc. are assumed to be periodic then the temperature distribution below earth surface at depth $x$, will also be periodic and may be written as follows [23],

$T(x, t)=T_{0}(x)+\operatorname{Re} \sum_{n=1}^{\infty} T_{n}(x) e^{i n \omega t}$

On substituting the value of $T(x, t)$ into equation (1) and solving the real and imaginary part separately one can get the expression of temperature distribution as following

$T(x, t)=$

$A x+B+$

$\operatorname{Re} \sum_{n=1}^{\infty}\left\{C_{n} \exp \left(-\beta_{n} x\right)+D_{n} \exp \left(\beta_{n} x\right)\right\} \exp (i n \omega t)$ where, $\mathrm{A}, \mathrm{B}, \mathrm{C}_{\mathrm{n}}, \mathrm{D}_{\mathrm{n}}$ are the constants and $\beta_{n}=\sqrt{\frac{n \omega \rho c}{2 K}}(1+$
i).

The constants can be determined by using the boundary condition. For the semi-infinite ground surface, as $x \rightarrow \infty, T(x, t) \rightarrow 0$, therefore $A=0$ and $D_{n}=0$. Then equation (3) reduces to,

$T(x, t)=B+\operatorname{Re} \sum_{n=1}^{\infty}\left\{C_{n} \exp \left(-\beta_{n} x\right)\right\} \exp (i n \omega t)$

Further the boundary condition at $x=0$, is as following

$h_{1}\left(T_{s a}-T_{x=0}\right)=-K\left(\frac{\partial T}{\partial x}\right)_{x=0}$

where $T_{s a}=\frac{\alpha}{h_{1}} I(t)+T_{a}-\frac{\varepsilon \Delta R}{h_{1}}$ is solair temperature at ground surface.

The hourly variation of solair temperature can be expressed in terms of Fourier coefficients for six harmonics as follows

$T_{s a}=T_{s a 0}+\sum_{n=1}^{6} T_{s a n} e^{i\left(n \omega t-\varphi_{n}\right)}$

From equations (4), (5) and (6) one can get,

$$
B=T_{s a 0} \text { and } C_{n}=\frac{h_{1} T_{s a n} e^{-i \varphi_{n}}}{h_{1}+K \beta_{n}}
$$

On substituting one can get

$T(x, t)=T_{s a 0}+\sum_{n=1}^{6} \frac{h_{1} T_{s a n} e^{-\beta n x}}{h_{1}+K \beta_{n}} e^{i\left(n \omega t-\varphi_{n}\right)}$

To calculate the average ground temperature for a particular month, the average solar intensity and ambient temperature have been taken as input parameters.

\section{Outlet Air Temperature of Earth Air Heat Exchanger}

Following Goshal et al. [11], the assumption for thermal modeling has been listed as below:

- "Analysis is based on quasi steady-state and heat flow is one dimensional [11]";

- "Flow of air is uniform along the length of buried pipes [11]";

- "There is no radiative heat exchange between the sides of the buried pipe [11]".

- Heat losses from room air to ambient is negligible.

- Room heating/cooling is done under open loop condition.

Referring to Fig. (1), the energy balance for an elemental length ' $d x$ ' can be written as [24]:

$\dot{m}_{a} C_{a} \frac{d T(x)}{d x} d x=2 \pi r h_{c}\left(T_{0}-T(x)\right) d x$

On solving the above equation with boundary conditions at $x=0, T(x)=T_{f i}$ and at $x=L, T(x)=T_{0}$ one can get,

$T_{f o}=T_{0}\left(1-e^{-\frac{2 \pi r h_{c} L}{\dot{m}_{a} C_{a}}}\right)+T_{f i} e^{-\frac{2 \pi r h_{c} L}{\dot{m}_{a} C_{a}}}$

The thermal energy gain by the air from the EAHE is given by,

$$
\begin{array}{r}
\dot{Q}_{u}=\dot{m}_{a} C_{a}\left(T_{f o}-T_{f i}\right) \\
\dot{Q}_{u}=\dot{m}_{a} C_{a}\left(T_{0}-T_{f i}\right)\left[1-e^{-\frac{2 \pi r h_{c} L}{\dot{m}_{a} C_{a}}}\right]
\end{array}
$$

If $\mathrm{v}$ is the velocity of air inside the EAHE and $\mathrm{V}$ is the volume of the room then, the number of air changes $(\mathrm{N})$ per hour is given as

$N=\frac{\pi r^{2} v \times 3600}{V}$

The pressure difference and the power required to pump the air through the earth air heat exchanger is given by

$\Delta P=F\left(\frac{\dot{M}_{a}}{\rho}\right)\left(\frac{L}{D}\right)^{3}$, where $F=F_{0}+\gamma\left(\frac{D}{L}\right)$

Power $=\dot{m}_{a} \frac{\Delta P}{\rho}$

The RPM of the fan is expressed as,

$N_{0}=\frac{60 \times v}{\pi \times D}$

\section{METHODOLOGY}

To design the earth air heat exchanger following methodology has been adopted

- $\quad$ The thermocouples for taking the temperature of the ground have been calibrated with the glass thermometer. 


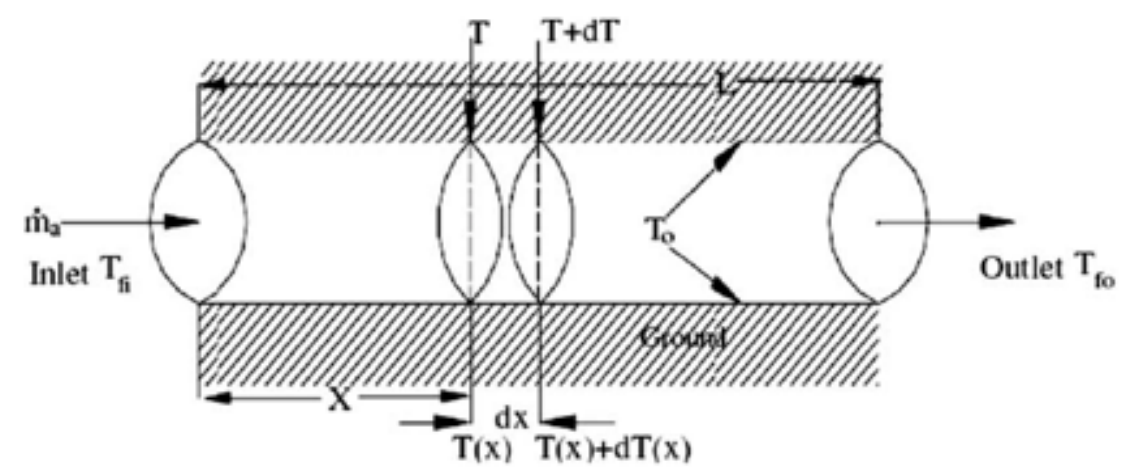

Fig. (1). Flow direction of air through an elemental length ' $d x$ ' inside earth air heat exchanger.

- $\quad$ The solar intensity and ambient temperature had been taken in the month of October for seven days.

- $\quad$ Corresponding to above solar intensity and ambient temperature, the experimental observations for the ground temperature at different depths have been taken.

- The above experimental observations have been validated with theoretically calculated ground temperature by taking different values of the thermal conductivity and the thermal diffusivity of the soil and thermal conductivity has been evaluated.

- $\quad$ For the evaluated value of thermal conductivity, the monthly average temperatures for different depths have been calculated and the depth of the heat exchanger has been optimized.

- $\quad$ For the evaluated thermal conductivity and optimized depth, the EAHE has been designed for a given number of air changes for different values of diameter and length of the pipe.

- $\quad$ For room of length $4.5 \mathrm{~m}$, breadth $4.5 \mathrm{~m}$ and height $2.6 \mathrm{~m}$, for desired number of air changes and power requirement the optimum design has been chosen. Parameters given in Table $\mathbf{1}$ have been used in the calculations.

Table 1. Values of different parameters used in analysis.

\begin{tabular}{|l|l|}
\hline$\alpha=0.3$ & $v=1.0 \mathrm{~m} / \mathrm{s}$ \\
\hline$\epsilon=0.9$ & $h_{c}=K_{a} N u / d \mathrm{~W} / \mathrm{m}^{2} \mathrm{~K}$ \\
\hline$K=0.540 \mathrm{~W} / \mathrm{mK}$ & $N u=0.023 R e^{0.8} \mathrm{Pr}^{0.3}$ \\
\hline$\rho=2050 \mathrm{~kg} / \mathrm{m}^{3}$ & $R e=v d / v$ \\
\hline$c=1840 \mathrm{~J} / \mathrm{kg} \mathrm{K}$ & $K_{a}=0.026 \mathrm{~W} / \mathrm{mK}$ \\
\hline$C_{a}=1005 \mathrm{~J} / \mathrm{kg} \mathrm{K}$ & $v=15.68 \times 10^{-6} \mathrm{~m}^{2} / \mathrm{s}$ \\
\hline$h_{1}=5.7+3.8 v ; W / \mathrm{m}^{2} \mathrm{~K}$ & $P r=0.708$ \\
\hline
\end{tabular}

\section{RESULT AND DISCUSSION}

Fig. (2) shows the hourly variation of solar intensity and ambient temperature for a typical day in the month of October at Sriperumbudur. From the figure one can observe that the maximum ambient temperature was obtained at around $3 \mathrm{pm}$. Corresponding to the above solar intensity and ambient temperature, the ground temperature at different depths has been recorded and shown in Fig. (3). It can be inferred from the figure that, as the depth increases the temperature decreases and approaches to a constant value. For $3 \mathrm{pm}$ the ground temperatures at $0.3 \mathrm{~m}, 0.6 \mathrm{~m}, 0.9 \mathrm{~m}$, and $1.2 \mathrm{~m}$ were $28.0{ }^{0} \mathrm{C}, 25.8{ }^{0} \mathrm{C}, 25.5{ }^{0} \mathrm{C}$ and $25.4{ }^{0} \mathrm{C}$ respectively.

The experimental validation of ground temperature at 0.3 $\mathrm{m}$ depth is shown in Fig. (4). The theoretical results are closer to the experimental results within the experimental limits of errors. Theoretically, calculated ground temperature for wetted surface has also been given in this figure for comparison purpose and it has been noticed that, to decrease the ground temperature further, one can wet the ground surface.

Further, for the evaluated value of thermal conductivity of soil, the depth of the heat exchanger has been optimized on monthly basis. For optimizing the depth, the monthly average of solar intensity and ambient temperature provided by the Indian meteorological department have been taken as input parameters for calculating the ground temperature on annual basis.

For calculating the monthly average ground temperature the monthly average of solar intensity and ambient temperature as shown in Fig. (5) have been taken as input climatic parameters. The monthly average ground temperature has been shown in Fig. (6). From the figure it is clear that, on monthly basis, the ground temperature for bare surface was nearly constant and nearly equal to $29{ }^{0} \mathrm{C}$ for optimized depth of $4 \mathrm{~m}$. For wetted surface, the ground temperature varied from $27-29{ }^{0} \mathrm{C}$ at $4 \mathrm{~m}$ depth, varied from $27-28{ }^{0} \mathrm{C}$ at $6 \mathrm{~m}$ depth and was nearly constant and equal to $28{ }^{0} \mathrm{C}$ at $9 \mathrm{~m}$ depth. Fig. (7) depicts the variation of outlet air temperature of EAHE along the length of the EAHE for two different number of air changes namely $\mathrm{N}=5$ and $\mathrm{N}=15$; and $0.1 \mathrm{~m}$ pipe diameter. One can see from the figure that, for larger pipes the outlet air temperature approaches to constant ground temperature. For the average ambient temperature of $34{ }^{0} \mathrm{C}$ in summers and $23{ }^{0} \mathrm{C}$ in winters, the outlet air temperatures of EAHE were $29.3{ }^{0} \mathrm{C}$ and $28.6{ }^{0} \mathrm{C}$ respectively. For both the seasons, the lengths of the EAHE corresponding to these outlet air temperatures were $21 \mathrm{~m}$ and $25 \mathrm{~m}$ for a numbers of 5 and 15 air changes respectively.

The variation of outlet air temperature of EAHE for $0 \mathrm{a}$ number of 5 air changes and two different diameters $(0.05 \mathrm{~m}$ and $0.10 \mathrm{~m}$ ) of pipe in summer and winter has been shown in 


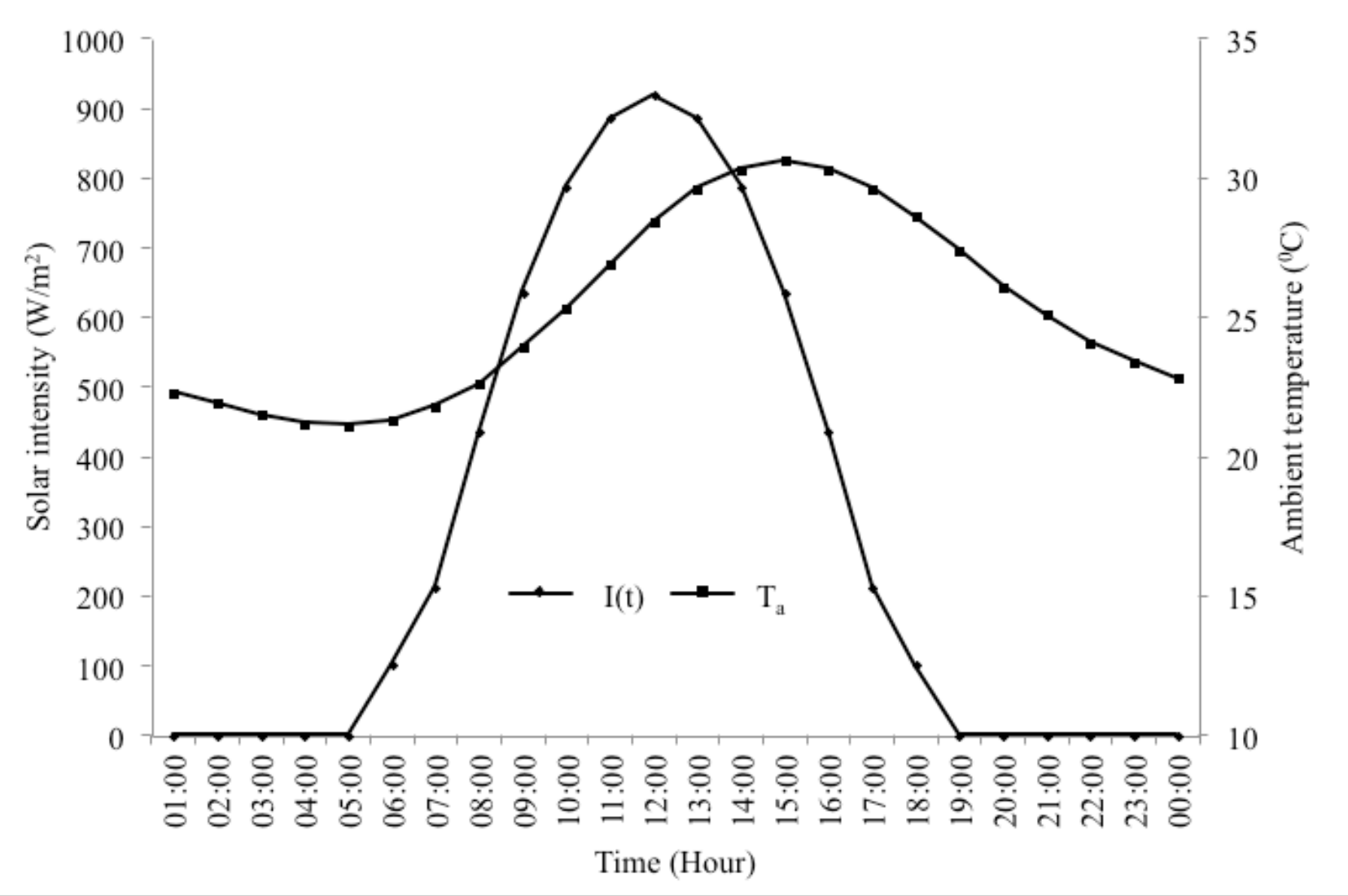

Fig. (2). Hourly variation of solar intensity and ambient temperature (08/10/2013).

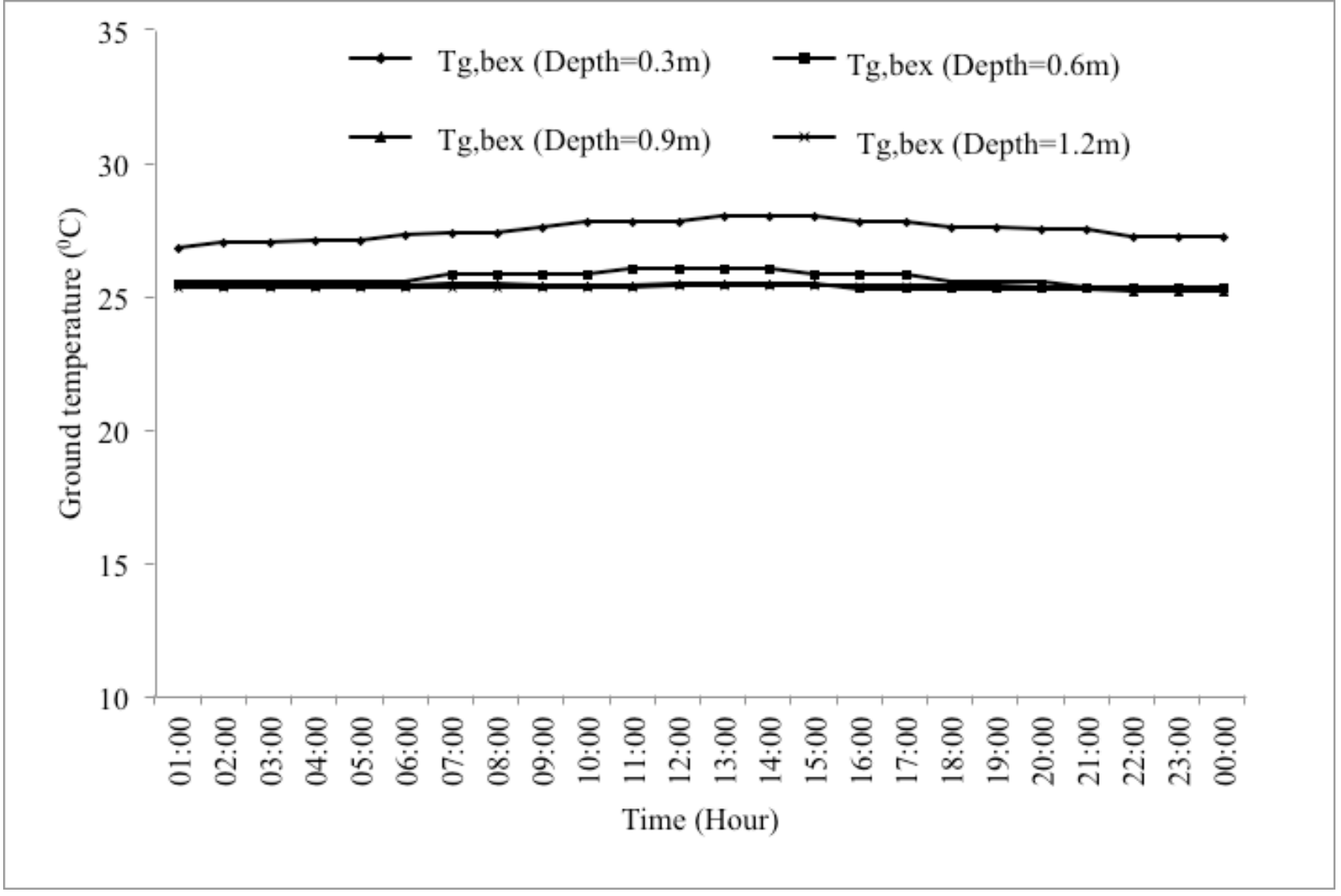

Fig. (3). Ground Temperature at different depth (Experimental) 


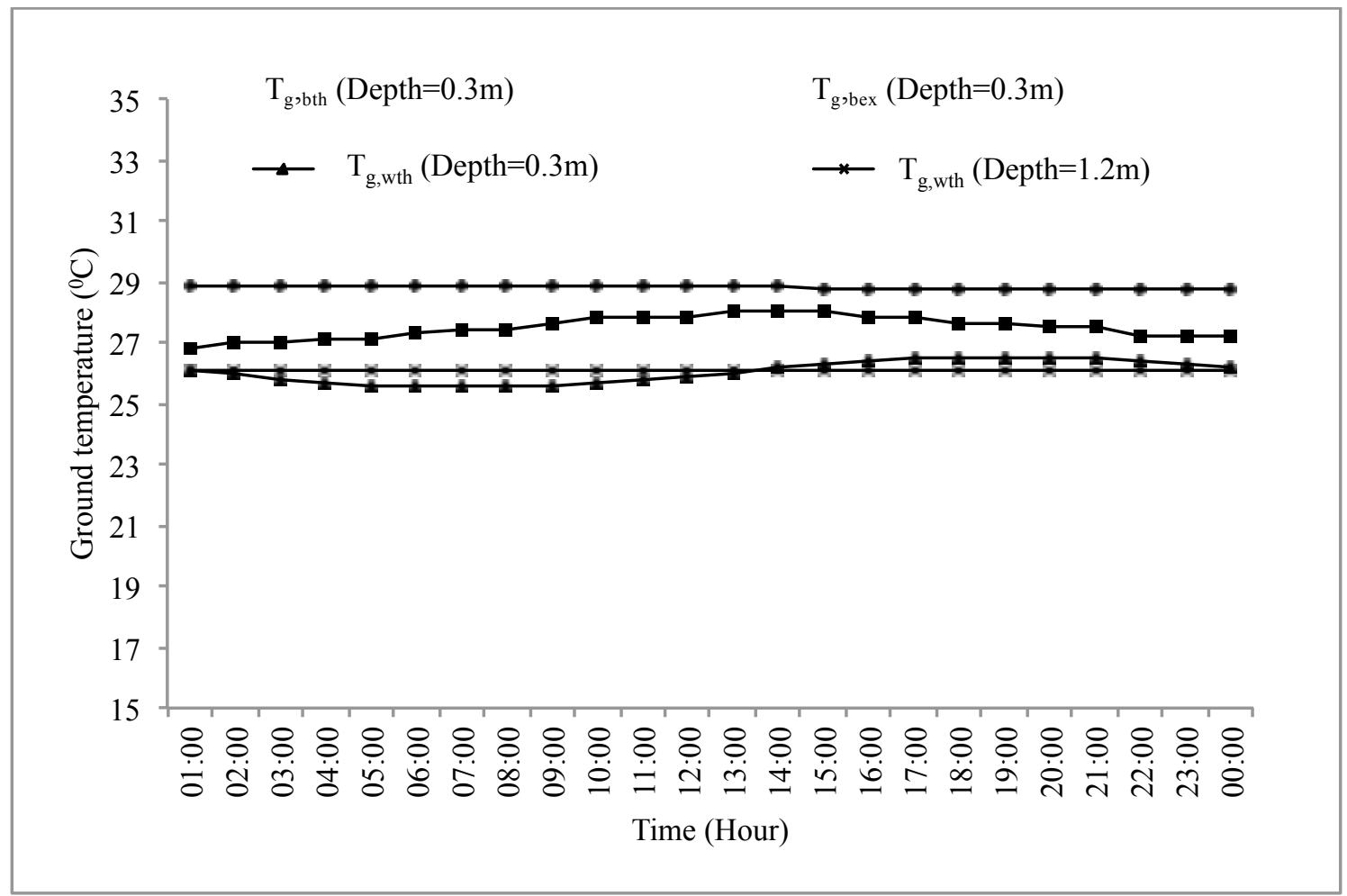

Fig. (4). Ground Temperature for bare surface and wetted surface at different depth (Theoretical and Experimental).

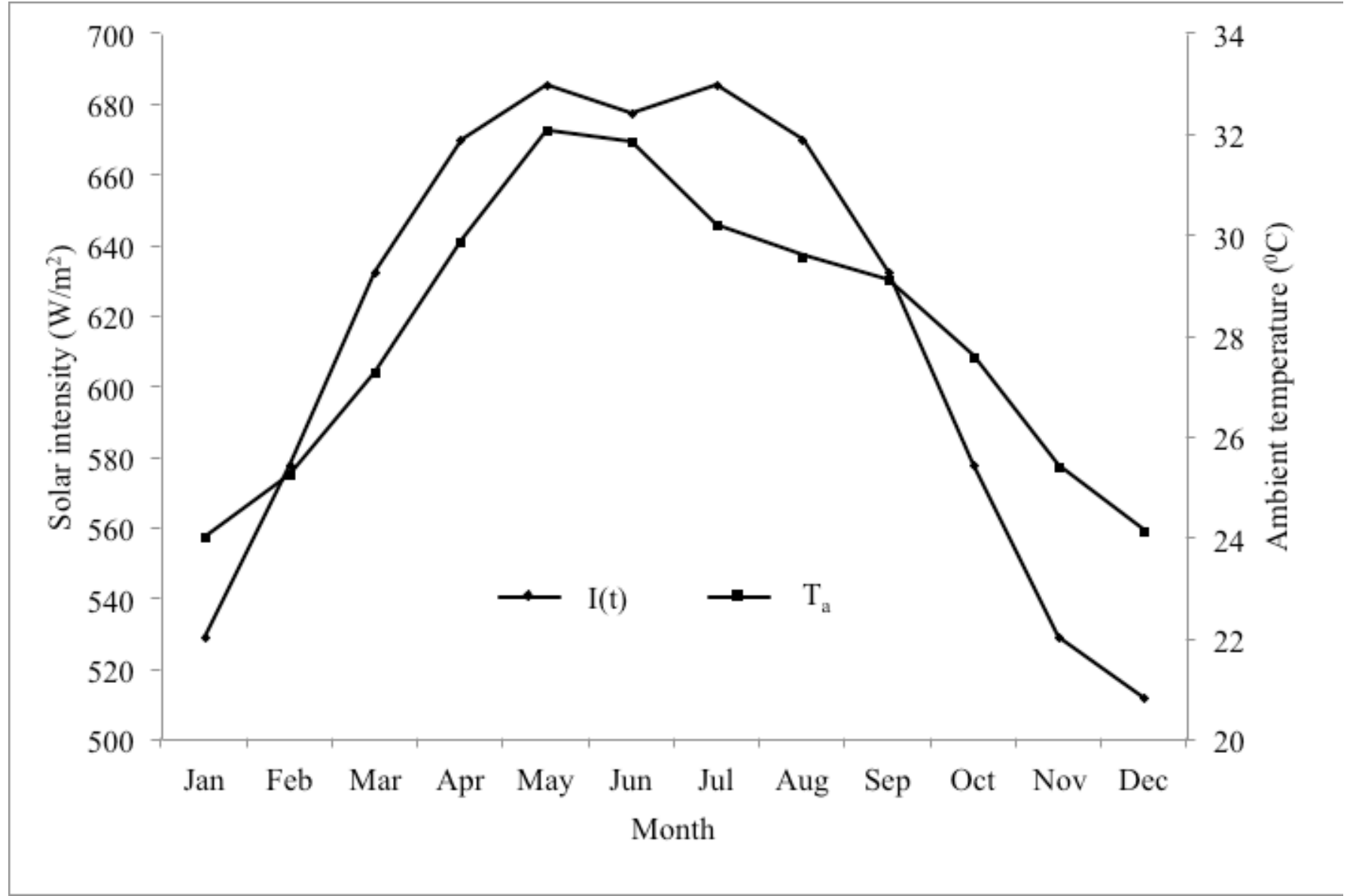

Fig. (5). Monthly variation of solar intensity and ambient temperature. 


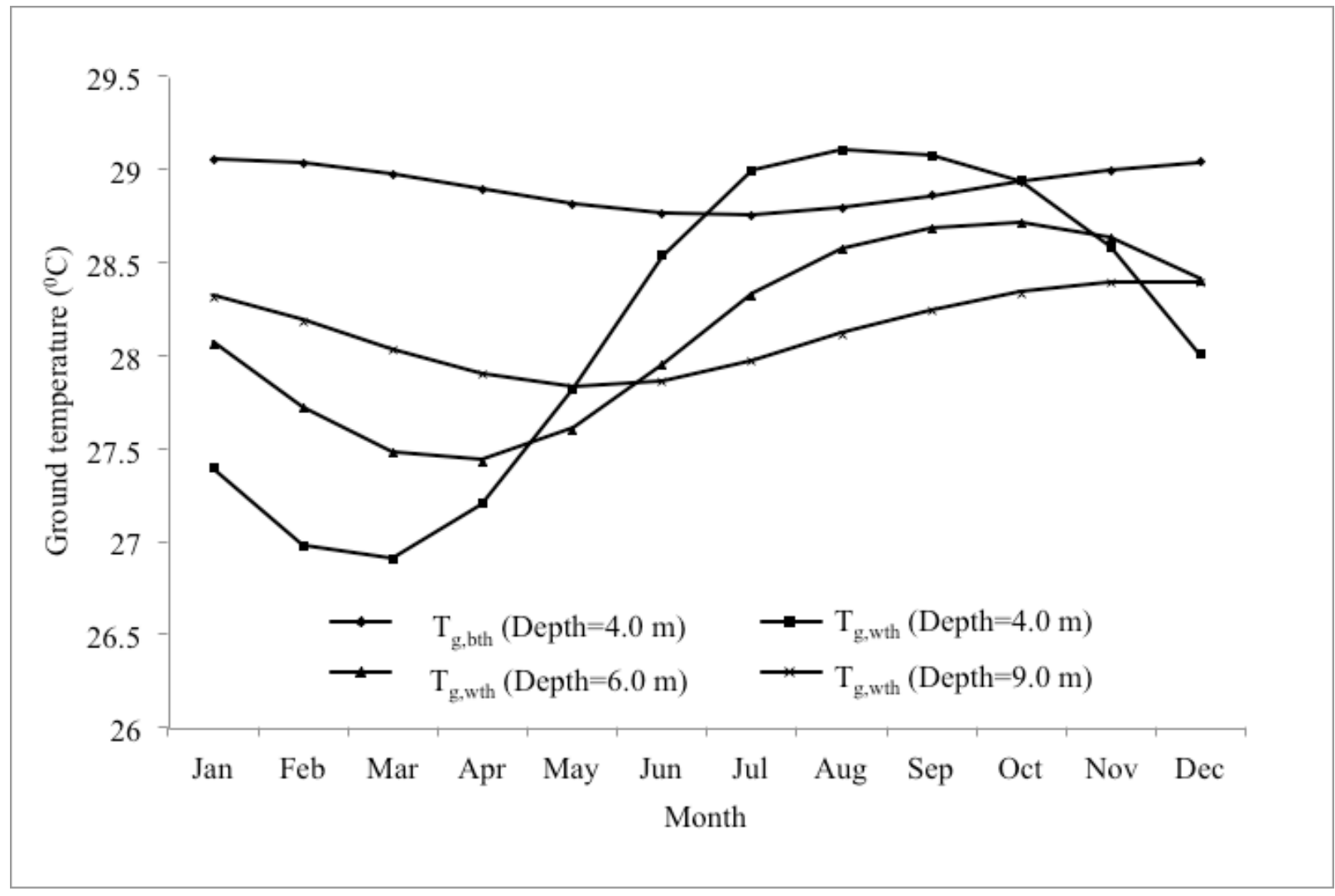

Fig. (6). Monthly ground temperature at different depth (Theoretical).

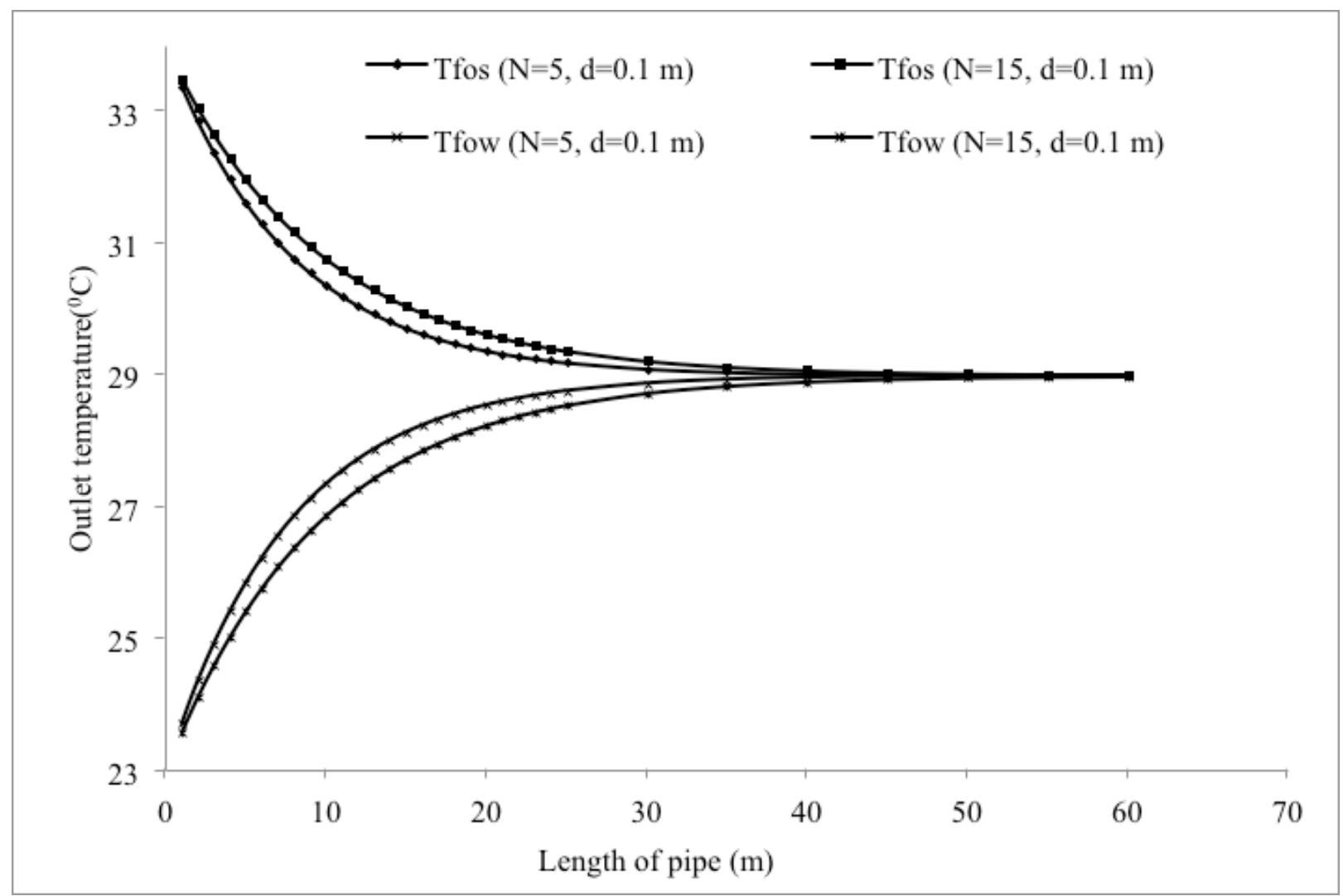

Fig. (7). Variation of outlet air temperature with length for pipe diameter $0.10 \mathrm{~m}$ and different number air changes $(\mathrm{N}=05,15)$. 


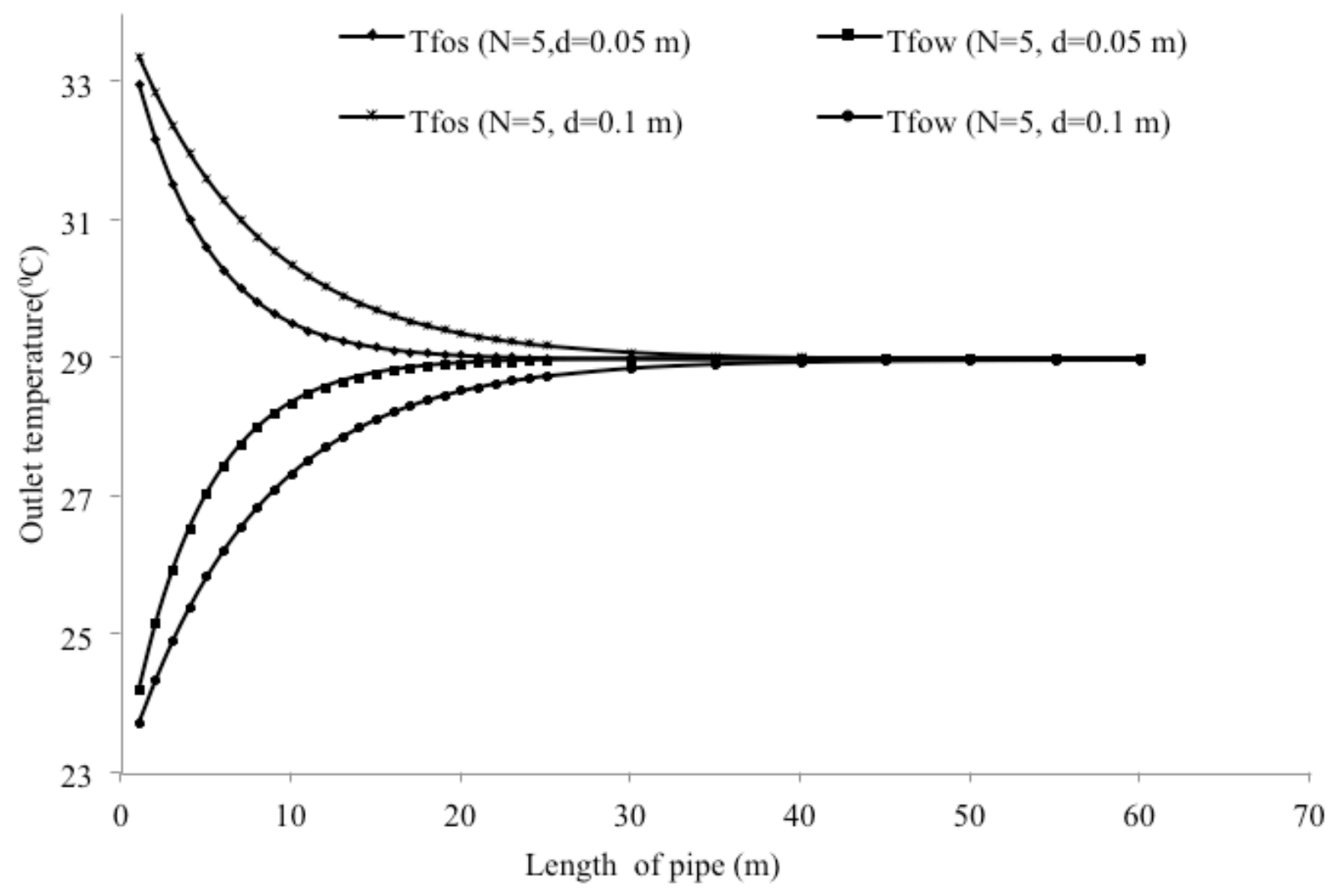

Fig. (8). Variation of outlet air temperature with length for pipe diameters $0.05 \mathrm{~m}$ and $0.10 \mathrm{~m}$ for different number air changes $(\mathrm{N}=05)$.

Fig. (8). One can see from the figure that, as the diameter of pipe increases, the optimized length for the desired outlet air temperature $\left(29.3{ }^{0} \mathrm{C}\right.$ for summer and $28.6{ }^{\circ} \mathrm{C}$ for winter) from the EAHE increases (length $=15 \mathrm{~m}$ for diameter $=0.05 \mathrm{~m}$; length $=21 \mathrm{~m}$ for diameter $=0.10 \mathrm{~m}$ ). It is due to the fact as the diameter of the pipe increases the volume of air to be cooled increases and hence the optimized length increases.

The useful thermal energy gain corresponding to calculated outlet temperature of EAHE has been plotted for $0.1 \mathrm{~m}$ diameter pipe for a number of 5 and 15 air changes and shown in Fig. (9). As the length of the pipe increases the useful gain increases and approaches to a constant value. For $0.05 \mathrm{~m}$ diameter and 5 number of air changes the useful energy gains were $0.45 \mathrm{kWh}$ for winter and $0.38 \mathrm{kWh}$ for summer; for 0.10 pipe diameter and 15 number of air changes the useful thermal energy gains were $1.4 \mathrm{kWh}$ and $1.2 \mathrm{kWh}$ for winter and summer respectively. The useful thermal energy gain in winters is higher as compared to summer because the limiting outlet temperature in summer was $29.3{ }^{\circ} \mathrm{C}$ for $34{ }^{0} \mathrm{C}$ average ambient temperature and in winter the limiting outlet temperature was $28.6{ }^{0} \mathrm{C}$ for $23{ }^{0} \mathrm{C}$ average ambient temperature.

For the optimized depth of $4 \mathrm{~m}$, the summarized result of the present analysis has been given in Table 2 . The two appropriate designs have been given as follows:

Design I: For a number of 5 air changes and $0.10 \mathrm{~m}$ pipe diameter, the optimized length of pipe is $21 \mathrm{~m}$. For air to be withdrawn from the pipe $0.09 \mathrm{~kW}$ power is required which can be achieved with a fan of diameter $0.3 \mathrm{~m}$ and RPM 66.
Design II: For a number of 5 air changes and $0.05 \mathrm{~m}$ pipe diameter, the optimized length of pipe is $15 \mathrm{~m}$. For air to be withdrawn from the pipe $0.14 \mathrm{~kW}$ power is required which can be achieved with a fan of diameter $0.3 \mathrm{~m}$ and RPM 66.

The environmental assessment is strongly associated with the calculation of cost of greenhouse gases $\left(\mathrm{CO}_{2}\right.$ is one of the major contributors of greenhouse gases). In the present case the energy gain of the system is effective reduction in the use of conventional sources of energy, hence reduction in the emission of greenhouse gases. Considering the effect of inefficiencies and distribution of losses, the amount of $\mathrm{CO}_{2}$ emitted per $\mathrm{kWh}$ production of electricity for Indian conditions is $2.04 \mathrm{~kg}$ [25]. The international carbon price is between $13 \$ / \mathrm{tCO} 2$ and $16 \$ / \mathrm{tCO} 2$ for the low and high pledge scenario [26]. Here cost calculation has been done for the average price i.e. $14.5 \$ / \mathrm{tCO}_{2}$. "Enviroeconomic (environmental cost) analysis based on these $\mathrm{CO}_{2}$ emission and carbon price (or $\mathrm{CO}_{2}$ emission price) is made as follows:

$\mathrm{C}_{\mathrm{CO} 2}=\left(\mathrm{cCO}_{2}\right) \times\left(x \mathrm{CO}_{2}\right)$

where " $\mathrm{C}_{\mathrm{CO} 2}$ " is the environmental cost (enviroeconomic) parameter which is based on the environmental analysis $\left(\mathrm{CO}_{2}\right.$ emission price in a year) ( $\$$ /year), "cCO $\mathrm{CO}_{2}$ " is $\mathrm{CO}_{2}$ emission price per $\mathrm{tCO}_{2}\left(14.5 \$ / \mathrm{tCO}_{2}\right)$, and " $x \mathrm{CO}_{2}$ " is $\mathrm{CO}_{2}$ emission releasing in a year ( $\mathrm{tCO}_{2} /$ year)" [27].

For eight hours of operation in a day of EAHE, the net energy gain for Design I in summer is $2.32 \mathrm{kWh}$ and for winter $2.88 \mathrm{kWh}$; for Design II, the net energy gain in summer is $3.20 \mathrm{kWh}$ and for winter $3.84 \mathrm{kWh}$. To calculate 


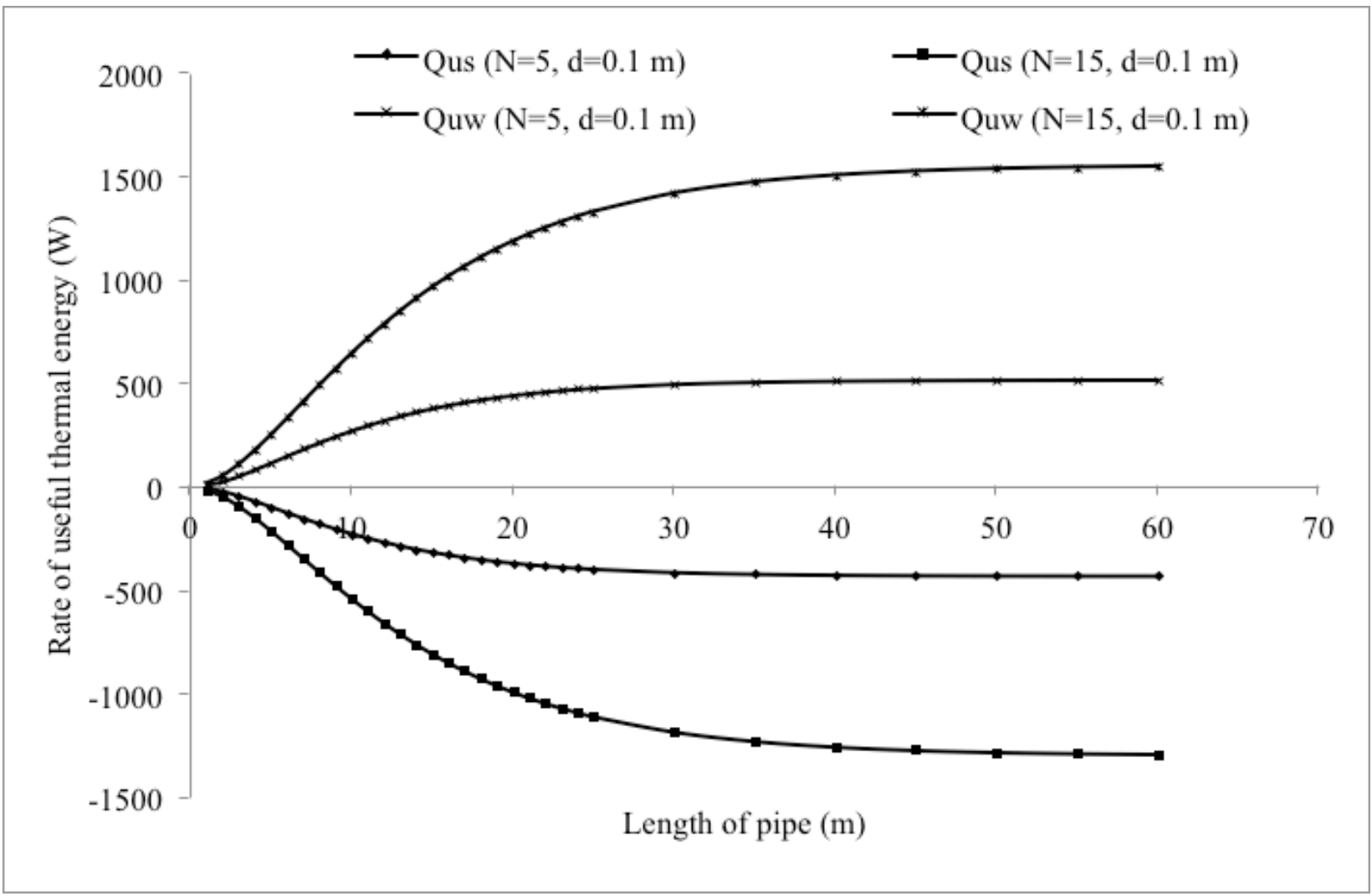

Fig. (9). Variation of useful energy with length for pipe diameter $0.10 \mathrm{~m}$ and different number air changes $(\mathrm{N}=05,15)$.

the reduction in the amount of $\mathrm{CO}_{2}$ emission in a year, it has been assumed that the system is in operation for 300 days in a year (excluding the days of winter seasons).

Reduction in $\mathrm{CO}_{2}$ emitted per year and corresponding environmental cost for Design I are $696 \mathrm{~kg}$ and $10.1 \$$ respectively; for Design II, these values are $960 \mathrm{~kg}$ and 13.9 $\$$ respectively for the dimensions of the room in the present study. The layout for the arrangements (series and parallel combination) of pipes for EAHE has been shown in Fig. (10). The pipes are connected in series to sum up to the total length equal to the optimized length for the chosen design.
For higher number of air changes, the parallel combination of such series connected pipes can be used.

Fig. (11) shows the lay out for single room integrated with the EAHE. The air to be cooled can be fed to the EAHE from ceiling of the room and the cooled air can be fed from the bottom of the room.

In urban locations, the underground space of the building should be utilized for the EAHE system which will be coupled with the building. To meet the electricity requirement for the operation of the EAHE system, one can

Table 2. For a given number of air changes the optimized length, power required and RPM of fan.

\begin{tabular}{|c|c|c|c|c|c|c|c|c|}
\hline S. No. & $\begin{array}{l}\text { Volume of } \\
\operatorname{Room}\left(\mathbf{m}^{3}\right)\end{array}$ & $\begin{array}{l}\text { No. of Air } \\
\text { Changes Per } \\
\text { Hour }\end{array}$ & $\begin{array}{l}\text { Diameter of } \\
\text { Pipe (m) }\end{array}$ & $\begin{array}{l}\text { Velocity in } \\
\text { Pipe }(\mathrm{m} / \mathrm{s})\end{array}$ & $\begin{array}{l}\text { Optimized } \\
\text { Length (m) }\end{array}$ & Power $(\mathrm{kW})$ & $\begin{array}{l}\text { Velocity for Fan }(\mathrm{m} / \mathrm{s}) \\
\text { (for Diameter }=\mathbf{0 . 3 ~ m )}\end{array}$ & $\begin{array}{c}\text { RPM } \\
(\text { for Diameter }=0.3 \mathrm{~m})\end{array}$ \\
\hline 1 & 52.65 & 5 & 0.05 & 37.3 & 15 & 0.14 & 1.1 & 65.9 \\
\hline 2 & 52.65 & 10 & 0.05 & 74.5 & 19 & 1.37 & 2.1 & 131.8 \\
\hline 3 & 52.65 & 15 & 0.05 & 111.8 & 21 & 8.06 & 3.1 & 197.7 \\
\hline 4 & 52.65 & 20 & 0.05 & 149.1 & 25 & 30.2 & 4.1 & 263.7 \\
\hline 5 & 52.65 & 25 & 0.05 & 186.3 & 25 & 57.1 & 5.2 & 329.6 \\
\hline 6 & 52.65 & 5 & 0.1 & 9.4 & 21 & 0.09 & 1.1 & 65.9 \\
\hline 7 & 52.65 & 10 & 0.1 & 18.6 & 25 & 1.05 & 2.1 & 131.8 \\
\hline 8 & 52.65 & 15 & 0.1 & 27.9 & 30 & 4.80 & 3.1 & 197.7 \\
\hline 9 & 52.65 & 20 & 0.1 & 37.3 & 35 & 15.20 & 4.1 & 263.7 \\
\hline 10 & 52.65 & 25 & 0.1 & 46.6 & 35 & 28.70 & 5.1 & 329.6 \\
\hline
\end{tabular}




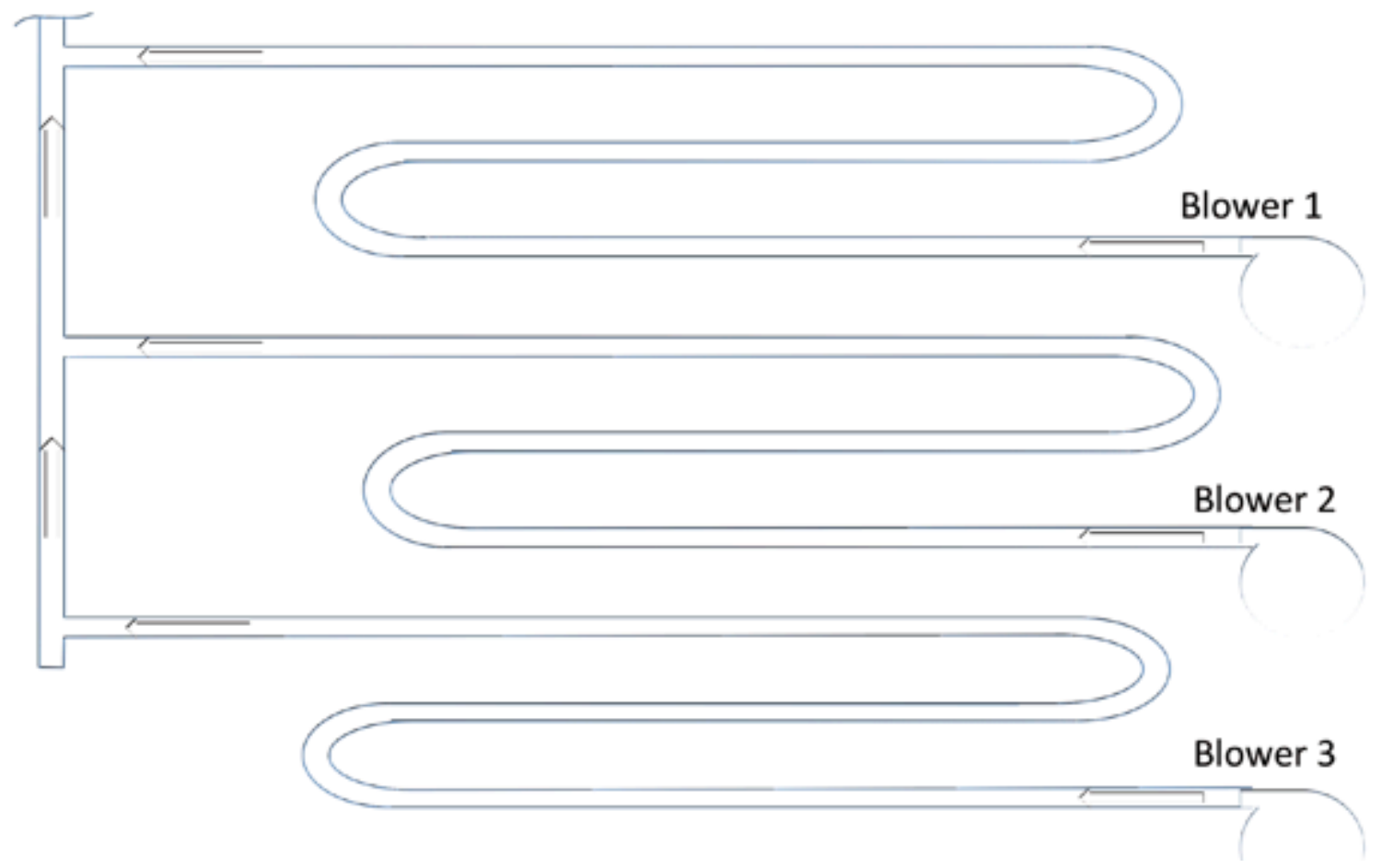

Fig. (10). Plan view of EAHE tubes arrangement in series and parallel.

also integrate the roof of the building with the photovoltaic module (a renewable energy source).

\section{CONCLUSION}

For Design I, the power required to operate the fan for desired number of air changes is $0.09 \mathrm{~kW}$ and the thermal energy gains in summer and winter are $0.38 \mathrm{~kW}$ and 0.45 $\mathrm{kW}$. Design I gives the net thermal energy gains of $0.29 \mathrm{~kW}$ and $0.36 \mathrm{~kW}$ in summer and winter respectively. For Design II, the power required for fan is $0.14 \mathrm{~kW}$ and the thermal energy gains in summer and winter are $0.40 \mathrm{~kW}$ and 0.48 $\mathrm{kW}$ respectively; corresponding net thermal energy gains are $0.26 \mathrm{~kW}$ and $0.34 \mathrm{~kW}$. The environmental cost for Design I and Design II are 10.1 \$ and 13.9 \$. It can be concluded that the use of EAHE can potentially reduce the load of heating or cooling by conventional sources.

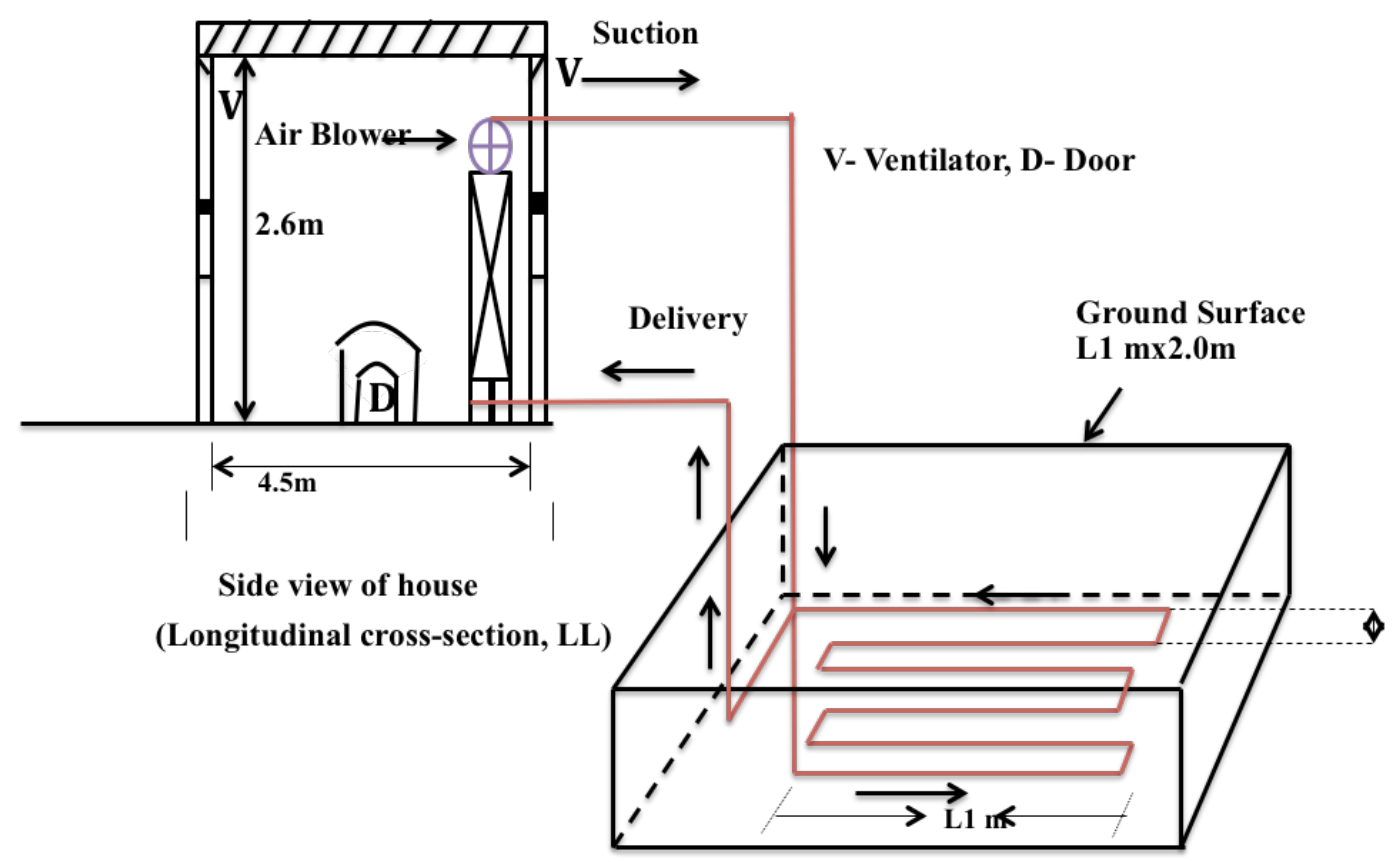

Fig. (11). Lay out for single room connected with earth air heat exchanger. 


\section{NOMENCLATURE}

$$
\begin{aligned}
& K=\text { Thermal conductivity of soil }(\mathrm{W} / \mathrm{mK}) \quad \dot{m}_{a}=\text { Mass flow rate of air in pipes }(\mathrm{kg} / \mathrm{s}) \\
& \rho=\text { Density of soil }\left(\mathrm{kg} / \mathrm{m}^{3}\right) \quad C_{a}=\text { Specific heat of air }(\mathrm{J} / \mathrm{kg} \mathrm{K}) \\
& c=\text { Specific heat of soil }(\mathrm{J} / \mathrm{kg} \mathrm{K}) \quad L=\text { Length of the pipe }(\mathrm{m}) \\
& T=\text { Ground Temperature }\left({ }^{0} \mathrm{C}\right) \\
& T_{0}=\text { Ground temperature outside pipe }\left({ }^{0} \mathrm{C}\right) \\
& t=\text { Time (s) } \\
& \omega=\text { Angular frequency }\left(s^{-1}\right) \\
& n=\text { Number of hormonics } \\
& \alpha=\text { Absoptiviy of the soil } \\
& \epsilon=\text { Emissivity of the ground surface } \\
& r=\text { Radius of pipe }(m) \\
& N=\text { Number of air changes } \\
& N_{0}=\text { RPM of the fan } \\
& I(t)=\text { Solar intensity }\left(W / m^{2}\right) \\
& T_{a}=\text { Ambient temperature }\left({ }^{0} \mathrm{C}\right) \\
& D=\text { Diameter of the pipe }(\mathrm{m}) \\
& T_{s a}=\text { Solair temperature }\left({ }^{0} \mathrm{C}\right) \\
& T_{f i}=\text { Air temperature at the inlet of earth air heat exchanger }\left({ }^{0} \mathrm{C}\right) \\
& T_{f o}=\text { Air temperature at the outlet of the earth air heat exchanger }\left({ }^{0} \mathrm{C}\right) \\
& h_{1}=\text { Total heat transfer coefficient from ground surface to the ambient }\left(\mathrm{W} / \mathrm{m}^{2} \mathrm{~K}\right) \\
& \Delta R=\text { Long wavelength radiation exchange from ground to the sky }\left(W / \mathrm{m}^{2}\right) \\
& h_{c}=\text { Heat transfer coefficient from inner surface of pipe to the air }\left(\mathrm{W} / \mathrm{m}^{2} \mathrm{~K}\right) \\
& K_{a}=\text { Thermal conductivity of air }(W / m K)
\end{aligned}
$$

\section{CONFLICT OF INTEREST}

The authors confirm that this article content has no conflict of interest.

\section{ACKNOWLEDGEMENTS}

The Authors are thankful to the BAG Energy Research Society, Varanasi, India and Rajeev Gandhi National Institute of Youth development, Sriperumbudur, India, an institution under ministry of sports and youth affairs Government of India for allowing conducting the experiments. Authors are also thankful to Mr. Lakhmi Chand for supporting the experimental observations.

\section{REFERENCES}

[1] Sodha MS, Bansal NK, Seth AK. Variance of the ground temperature distribution. Appl Energ 1981; 8: 245-54.

[2] Ozgener O, Ozgener L, Tester JW. A practical approach to predict soil temperature variations for geothermal (ground) heat exchangers applications. Int J Heat Mass Transfer 2013; 62: 47380 .

[3] Bowen A, Clark E, Labs K. Eds., Proc Int Passive and Hybrid Cooling Conference; 1981: Miami Beach, Florida. Newark, Delaware: American Section of ISES, 1981.

[4] Sinha RR, Goswami DY, Klett DE. Theoretical and experimental analysis of cooling technique using underground air pipe. Paper presented at the Solar World Forum 1981, Brighton, UK.

[5] Sodha MS, Sharma AK, Singh SP, Bansal NK, Kumar A. Evaluation of an earth-air tunnel system for cooling/heating of a hospital complex. Build Environ 1985; 20(2): 115-22.

[6] Mavroyanopoulos GN, Kyritsis S. The performance of a greenhouse heated by an earth - air heat exchanger. Agr Forest Meteorol 1986; 36: 263-68.

[7] Tzaferis A, Liparakis D, Santamouris M, Argiriou A. Analysis of the accuracy and sensitivity of eight models to predict the performance of earth-to-air heat exchangers. Energ Buildings 1992; 18: 35-43.
[8] Mihalakakou G, Santamouris M, Asimakopoulos D, Papanikolaou N. Impact of ground cover on the efficiencies of earth-to-air heat exchangers. Appl Energ 1994; 48:19-32.

[9] Bojic M, Papadakis G, Kyritsis S. Energy from a two-pipe, earthto-air heat exchanger. Energy 1999; 24: 519-23.

[10] Pfafferott J. Evaluation of earth-to-air heat exchangers with a standardised method to calculate energy efficiency. Energ Buildings 2003; 35: 971-83.

[11] Ghosal MK, Tiwari GN, Das DK, Pandey KP. Modeling and comparative thermal performance of ground air collector and earth air heat exchanger for heating of greenhouse. Energ Buildings 2005; 37: 613-21.

[12] Nayak S, Tiwari GN. Theoretical performance assessment of an integrated photovoltaic and earth air heat exchanger greenhouse using energy and exergy analysis methods. Energ Buildings 2009; 41: 888-96.

[13] Nayak S, Tiwari GN. Energy metrics of photovoltaic/thermal and earth air heat exchanger integrated greenhouse for different climatic conditions of India. Appl Energ 2010; 87: 2984-93.

[14] Bansal V, Mishra R, Agarwal GD, Mathur J. Performance analysis of integrated earth-air-tunnel-evaporative cooling system in hot and dry climate. Energ Buildings 2012; 47: 525-32.

[15] Hepbasli A. Low exergy modelling and performance analysis of greenhouses coupled to closed earth-to-air heat exchangers (EAHEs). Energ Buildings 2013; 64: 224-30.

[16] Clara Peretti, Zarrella A, DeCarli M, Zecchin R. The design and environmental evaluation of earth-to-air heat exchangers (EAHE). Renew Sust Energ Rev 2013; 28: 107-16.

[17] Bisoniya, TS, Kumar A, Baredar P. Experimental and analytical studies of earth-air heat exchanger (EAHE) systems in India: A review. Renew Sust Energ Rev 2013; 19: 238-46.

[18] Li H, Yu Y, Niu F, Shafik M, Chen B. Performance of a coupled cooling system with earth-to-air heat exchanger and solar chimney. Renew Energy 2014; 62: 468-77.

[19] Chlela F, Husaunndee A, Riederer P, Inard C. Numerical evaluation of earth to air heat exchangers and heat recovery ventilation systems. Int J Vent 2006; 6(1): 42 (31).

[20] Rafael R, Maria BD. Analysis of the utilization of mine galleries as geothermal heat exchangers by means of a semi-empirical prediction method. Renew Energy 2009; 34:1716-25. 
[21] Thiers S., Peuportier B. Thermal and environmental assessment of a passive building equipped with an earth-to-air heat exchanger in France. Solar Energy 2008; 82: 820-31.

[22] Misra R, Bansal V, Agarwal GD, Mathur J, Aseri T. Thermal performance investigation of hybrid earth air tunnel heat exchanger. Energ Buildings 2012; 49: 531-5.

[23] Khatry AK, Sodha MS, Malik MA. Periodic variation of ground temperature with depth. Sol Energy 1978; 20: 425-7.

[24] Bansal NK, Sodha MS, Bhardwaj SS. Performance of earth air tunnels. Energy Res 1983; 7: 333-345.
[25] Nawaz I, Tiwari GN. Embodied energy analysis of photovoltaic (PV) system based macro and micro level. Energy Policy 2006; 34 3144-52.

[26] Den Elzen MG, Hof AD, Beltran AM, et al. The Copenhagen accord: abatement costs and carbon prices resulting from the submissions. Environ Sci Policy 2011; 14(1): 28-39.

[27] Caliskan H, Dincer I, Hepbasli A. Exergoeconomic, enviroeconomic and sustainability analyses of a novel air cooler. Energ Buildings 2012; 55: 747-56.

(C) Tiwari et al.; Licensee Bentham Open.

This is an open access article licensed under the terms of the Creative Commons Attribution Non-Commercial License (http: //creativecommons.org/licenses/by$\mathrm{nc} / 3.0 /$ ) which permits unrestricted, non-commercial use, distribution and reproduction in any medium, provided the work is properly cited. 